\title{
Technology and Innovation in Schoolchildren Training: Development of Musical and Acting Skills
}

\author{
M. V. Pereverzeva ${ }^{1, *}$, M. L. Kats ${ }^{1}$, V. A. Ovsyannikova ${ }^{2}$, S. S. Aksenova ${ }^{2}$, N. S. Yushchenko ${ }^{2}$ \\ ${ }^{1}$ Department of Sociology and Philosophy of Culture, Highest School of Music (Institute), Russian State Social University, Russia \\ ${ }^{2}$ Department of Arts and Artistic Creation, Highest School of Music (Institute), Russian State Social University, Russia
}

Received January 15, 2020; Revised May 4, 2020; Accepted May 20, 2020

Copyright $(2020$ by authors, all rights reserved. Authors agree that this article remains permanently open access under the terms of the Creative Commons Attribution License 4.0 International License

\begin{abstract}
Today, the main problem of additional education institutions is comprehensive pre-professional training, allowing students to master the professions of musician, dancer, or actor. In recent decades, there has been a tendency to narrow specialization in teaching children, which is the reason why modern educators seek to improve programs. The purpose of the work is to determine the content and identify innovative teaching technologies, in particular, those related to the development of musical and acting abilities. Study methods include the analysis of modern experience in applying traditional and innovative approaches to develop musical and acting skills and testing the most effective pedagogical technologies of creative development of schoolchildren. The conclusions of the study are related to the fact that the comprehensive development of schoolchildren implies not only the development of basic skills and abilities, but also the formation of artistic taste and musical and acting skills. This is necessary to create artistic images in various types of art, which needs to be taught from early childhood. An important aspect of the study is the belief that comprehensive pre-professional training of students allows one to reveal all aspects of the child's personality and determine the direction of their future professional path. Basic musical and acting skills necessary for many areas of professional activity are easily acquired in childhood due to the psychophysiological characteristics of students. Thus, the problem of the development of musical and acting skills in schoolchildren, which requires innovative approaches and modern pedagogical technologies, is actualized.
\end{abstract}

Keywords Acting Abilities, Innovation, Musical Abilities, Schoolchildren, Training

\section{Introduction}

Russian general education institutions are famous for the actively artistic and creative development of children, including their musical and acting abilities [1-3]. However, recently, these abilities in school have been neglected, which results in problems in the professional preparation of children to creative activity [4]. Today, "fundamentally new aesthetic tasks facing contemporary art and art education" require solution $[5, \mathrm{p} .170]$. One of them is the development of the ability to understand and express, using acting and musical skills, the imagery and artistic intention of works of art, from folklore to avant-garde. Due to early professionalization, the formation of musical and acting abilities is aimed primarily at further professional self-determination of art school graduates [6]. "In the early stages of education, the foundation of performance skill is formed and features of the nature of the artist's talent are brought out" [7, p. 101].

The elementary school "Russia-XXI Century" program, approved by the Ministry of Education and Science in 2010, includes educational technologies used in training of musicians and actors, and adapted for students. The use of these technologies resulted in a noticeable increase in the level of development of musical and acting skills of children and led to an increase in the number of children entering children's art schools and colleges, as well as participating in children's creative contests. In recent years, there has been boom in music and theater festivals and competitions in Russia (The Nutcracker, The Blue Bird, The Young Musician), including television shows (Best of All, Voice Kids, etc.).

At present, musical education often lags behind general education. In modern Russia, it is usually received in the system of additional and vocational education. While in music schools, special disciplines include basic-level music courses, in children art schools or amateur groups, the study of music is limited. Acting skill is even more neglected. Moreover, "the formation of singing and acting skills often becomes a priority, obscuring the creative component of the future profession" [8, p. 61]. However, in childhood, one forms emotional responsiveness to music, 
as well as imagination as the foundation of acting skill. Music also allows for solving various problems common among disabled children [9].

The actor's training, required by future artists no less than physical or psychological training, is also lagging behind in the general education system of children. Basic acting skills are easily acquired precisely in childhood due to the psychophysiological characteristics of students. Children comprehend the world by way of copying and imitating it, thereby showing acting abilities which must be developed further by novice dancers. Thus, the problem of developing musical and acting skills in schoolchildren, which requires innovative approaches and modern pedagogical technologies, is being actualized $[10,11]$.

\section{Literature Review}

The close connection between musical and acting skills has remained in art since antiquity and to the present day. Its consideration by schoolchildren at music classes allows for a deeper understanding of the essence of music and performance art. The problem of the connection between music and other art forms is fundamental in art theory and history. However, this field of schoolchildren knowledge is considered later than required. All disciplines of pre-professional education must be connected and, in their unity, encourage the formation of the foundations of artistic culture. Moreover, "music education is capable of providing the maximal implementation of the principles of complexity and integration of the most important education systems and methodologies for professional creative education" [5, p. 171].

Given the above, according to E.N. Yakovleva, the problem of musical education as an attribute of the development of musical skills of a student is gaining importance. In modern conditions of musical education development, musical and educational activity should be considered as a process of conscious, active and purposeful interaction between a teacher and an audience, which is predetermined by the individual's independent position in choosing musical values and is aimed at disseminating musical and aesthetic knowledge in order to enhance the spiritual development of a person [12]. Musical and educational activities should contribute to the formation of individual qualities in modern students by way of comprehending the personal contained in musical works, such as finding their own word first in art and then in life. Participation in musical and educational activities is an important result of the aesthetic education of schoolchildren, and their efforts and initiative in the process of such activity are essential indicators of the aesthetic education of a future school graduate. Musical and educational activities are a specific way of realizing the creative abilities of students and an integral factor in their general cultural development [12].

According to S.L. Glebova, the organization of musical and educational activities implies involving children in the implementation and initiation of tasks of a creative nature that have school-wide significance, for example, participating in the preparation of events for children's philharmonic concerts, performances at parent-teacher meetings, and thematic concerts. Intellectual-creative and musical-artistic work in the school and beyond it consist not only in introducing students to the collection, storage and promotion of artistic values, but also in developing their responsibility for maintaining artistic values, fostering a sense of their own ability to create an artistic environment that will be interesting and useful for others. Such activity is associated with the formation in children of a focus on self-education and self-upbringing and is aimed at developing needs for improving knowledge, skills and independent work, an individual meaningful choice of creative activity, and self-esteem. [13]

As O.P. Melnik notes, the forms of conducting musical and educational events can be diverse: interactive music competitions, musical projects, conversation lessons with game elements, musical brain rings, performance lessons, computer quizzes that are not included in the curriculum but awaken and satisfy the aesthetic needs of students, shape tastes; discussion of books about music and musicians, television and radio broadcasts, exchange of impressions, etc. The teacher, according to the researcher, must necessarily take into account the interests of students, encourage them to become the creator in the process of perception of musical works, which will contribute to the development of students' listening culture, their musical erudition, memory, attention and perception of multigenre music [14]

Theatrical activity, as the methodologists indicate [15], allows students to master knowledge in the field of musical art, and subject to pedagogically expedient organization and optimal selection of educational methods, and can become an effective factor in the formation of the aesthetic culture of modern children and the acquisition of acting skills. One of the most significant functions of musical and theatrical activity for the development of the personality of a modern child is artistic and cognitive function aimed at expanding the horizons and enriching the musical and theatrical thesaurus of schoolchildren. Creative activity of schoolchildren in the field of theater contributes to the activation of these processes. During musical and theatrical performances, students are especially willing to present their impressions of the characters' behavior, events, phenomena, etc., and for modern children this is especially important because they prefer watching TV programs, playing computer games. That is, theatrical art classes contribute to focusing on reality and increasing the sensitivity of students to the actions of other people, the development of the ability to see, understand the purpose and significance of various human actions.

Theatrical activity is an important factor in increasing the level of emotional susceptibility of students, 
developing their ability to evaluate actions in the field of aesthetic phenomena, ensuring the psychological discharge of children, which justifies its emotional and evaluative function.

As Z.A. Gavrilova notes, musical and theatrical activity serves to influence the formation of an aesthetic and evaluative attitude to reality, in particular to musical art. A modern student will achieve aesthetic awareness only if what the theater offers becomes intrinsically important for him, if the life portrayed in the play excites him, if the questions raised on the stage have direct or indirect significance for his spiritual development. At the same time, in her opinion, the formation of their artistic and aesthetic taste is an important aspect of educating students by the means of art in musical theater. The ability to perceive and understand a work of art, its content and form also requires an assessment of its artistic quality, the means of expression that the author uses to form images [16].

Due to the extreme informational richness of the educational process, the pace of life and the influence of individual negative social factors, one of the dominant needs of a modern student is the need for rest, psychological relaxation. The participation of students in creative activities in the field of musical and theatrical art, as A.N. Kuznetsov notes, is able to help minimize psychological stress and release their positive energy [17].

A significant function of musical and theatrical activity in the aesthetic education of children is musical and creative function. It consists in intensification of the artistic and creative activities of schoolchildren, the basis of which is the game, which is important, given the mainly passive lifestyle of modern children. In theatrical creativity, based on a dramatic play, the child's need for self-expression, self-affirmation is realized directly. This is manifested in the desire of schoolchildren to realize several functions at once in the process of musical and theatrical activity: musical and theatrical performance, the production of sets, costumes, elementary scenic and directorial work, etc. [18].

The musical and communicative function directs the student to the formation of creative cooperation skills in the musical collective and the development of communicative qualities during musical and stage activities. In the process of such activities, the child enters into a collective relationship, which contributes not only to the comprehension of the foundations of musical and theatrical culture, but also to the direct expansion of children's contacts and the acquisition of communication experience in the team. The important thing is that through musical theater activities the child expands the sphere of spiritual communication, gets the opportunity to transfer his experiences to other people [18].

So, summing up the analysis of scientific and methodological literature, it is possible to conclude that classes in musical and theatrical art expand the life and artistic horizons of modern schoolchildren, contribute to the enrichment of their musical and theatrical thesaurus, increase the level of emotional sensitivity of students, develop their ability to assess aesthetic phenomena, activate artistic and creative abilities. Such classes are important for developing students' skills of creative cooperation in the musical collective, developing the participants' communicativeness, and they arouse in children a sense of aesthetic pleasure from the perception of artistic creativity, from comprehending beauty in an integrative combination of various types of arts, and also realize the need of modern schoolchildren for psychological relaxation and rest.

At the same time, choreography is one of the main types of musical and theatrical art that organically combines the manifestation of musical and acting skills. $[2,8,19]$

\section{Methods}

\subsection{General Description}

The research methods included:

- theoretical analysis of modern experience in the application of traditional and innovative approaches to schoolchildren training aimed to develop musical and acting abilities,

- empirical testing of the most effective pedagogical technologies in the creative development of primary schoolchildren in choreography classes in Moscow schools.

\subsection{Algorithm}

The sources of theoretical analysis included the work of domestic and foreign researchers and methodologists on the problem of developing musical and acting skills of schoolchildren in musical and theatrical activities.

Since musical and acting abilities play a special role in teaching choreography to schoolchildren, the study of innovative methods for the development of musical and acting skills of children was carried out on the basis of choreography classes in primary schools in Moscow during the 2018-2019 school year.

The methodological basis for the selection and development of exercises was the method of physical action developed by K.S. Stanislavski, the goal of which is to activate the subconscious. Using specific exercises, performers learn to organize stage action through recital, singing, and movement, the nature of which organically stimulates a child's creative abilities [20]. 


\subsection{Flow Chart}

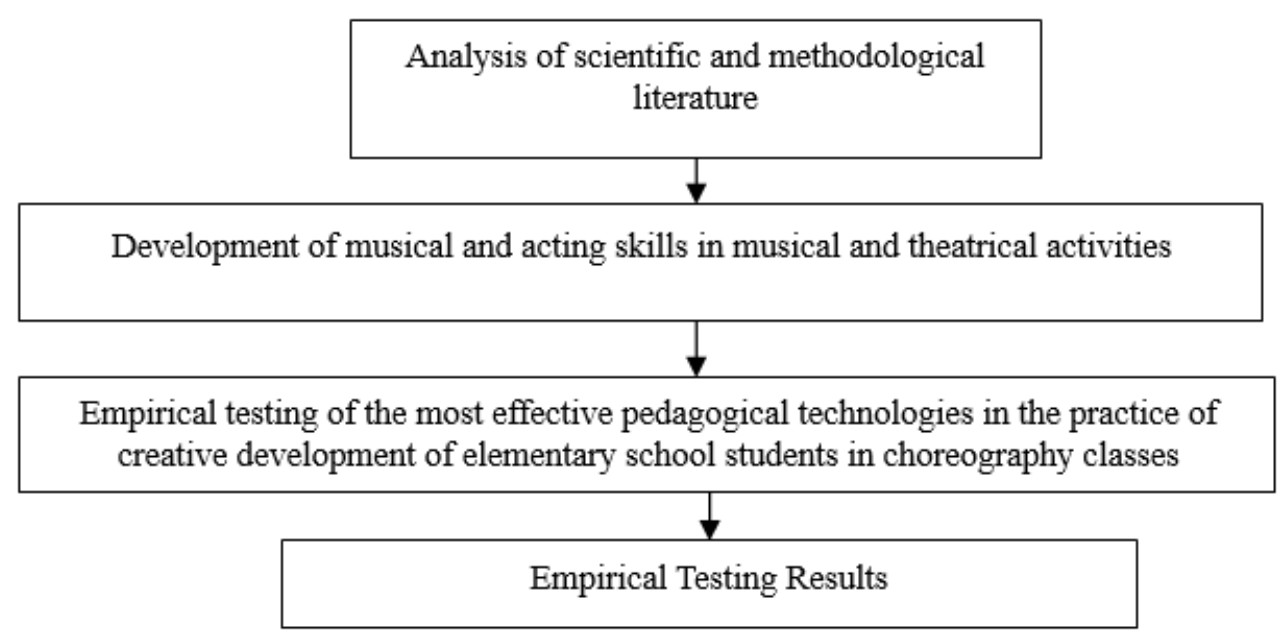

\section{Results}

At the choreography classes, special attention was paid to the development of plastic expressiveness in children since a dancer must clearly and vividly express everything that can be expressed using plasticity, pose, gesture, and action. A particular principle for the selection of exercises for schoolchildren is the emotional component of the exercises. Emotionality is determined by the use of musical material. To create a developed image, a schoolchild must understand the character, its emotions and aspirations and start working on the role when the image is comprehended. This skill is developed in the early stages of choreographic training [21]. The methodological basis for the development of musicality in children studying choreography relies on a stage-by-stage approach (the movement from introduction to general music concepts to mastering means of musical expressiveness and patterns of the development of form) and the correlation between the studied material and schoolchildren's level of understanding. The educational process must be engrossing and practice-oriented. First and foremost, it is necessary to stimulate in young dancers the interest and love for music since "the foundations of music culture, necessary for ballet dancers, are formed with the first sounds of music in the studio" [5, p. 171]. Music culture, the foundation of which is formed in pre-professional training, allows for successful mastering by students of choreographic schools of musical instruments, music theory, and music literature.

In the 21 st century, information technology plays a special role in quality management in education $[22,23$, 24]. It provides with comprehensive pre-professional preparation of schoolchildren.

Today, information technology plays an important role in the formation of musicality and acting abilities in young dancers. Thus, for the discipline "Choreography", the general education program includes mastering of dance and acting basics, including through ICT. As a result of mastering the discipline, the student must be able to rhythmically move to the music, work with recorded musical material, demonstrate plasticity, coordination, and positioning of the body, legs, arms, and head, and apply acquired performance skills in creative activity. Information and communications technology ensures the effective preparation of children. For example, children participate in the project "From beautiful images to absolute beauty", which includes 12 hours of classes devoted to each section of the program.

The project includes the teacher's presentation. Students are introduced to the topic and perform tasks, including independent group work on the Internet. The presentation ends with a choreographic class organized based on the principle of increasing complexity of musical development and various types of exercises. Children consider the transition from artistic images of a choreographic piece to their ideal embodiment in terms of technique, style, and taste. Children successfully master music elements by comparing them with visual images in the process of performing engrossing interactive computer-based tasks. Information technology also expands schoolchildren's aural experience and helps in the development of intonational and harmonic aural skills, sense of rhythm, memory, and imagination, as well as the acquisition of special knowledge in the field of music history and theory, genres and forms [25].

The development of musical abilities and analytical thinking encouraged the movement from rote learning to conscious performance, as well as analysis of various dynamic and spatial aspects. This significantly stimulated the mechanisms of choreographic training as a process, which brings out the creative individuality of each student. Thus, the work of the concertmaster with the dancers allowed for significant improvement of the quality and expressiveness of dance moves. An innovative personality-oriented approach, according to V.Y. Nikitin, 
helps "to develop creative abilities ... for the future professional activity, which in many ways depends on the technical opportunities and natural abilities of a child, such as acting abilities, etc." [26, p. 237].

\section{Discussion}

As the results of empirical testing of the most effective pedagogical technologies in the practice of creative development of elementary school students in choreography classes showed, in the early stages of teaching acting skills, teachers should pay attention to overcoming children's psychological difficulties, motivation for creative self-expression, and creation of productive atmosphere, which is supplemented by play, improvisation, and the polyartistic approach. Similar to musical skills, acting skills require a stage-by-stage approach and correlation between the studied material and schoolchildren's level of understanding. Of the stage-by-stage nature are the expansion of the boundaries of perception of the environment and emotional expression of a person and mastering of such expressive means as facial expressions, body plasticity, arms, legs, and head movements, as well as methods for developing images.

It is reasonable to begin with the simplest exercises, for example, following musical and rhythmic accents when dancing, determining the nature of an image, or describing the plot of a piece. Next, one can complicate the task by asking children to show it by using facial expressions, body movements, gestures, and other techniques heard or seen during the class. Children must learn and understand the expressive qualities of all technical movements and their combinations, characteristic of different choreographic styles. As a result, all components of performance skills of beginner dancers are formed, including "motor-technical, metrorythmical, and artistic-expressive" [27, p. 97].

However, a teacher must be both a psychologist and director, organizing classes in a way that allows children to consider all components of the concept of acting skill. As T.V. Bulgakova notes, "A tactical pedagogical goal is the combination of emotional and analytical tasks related to the expressive means of acting characteristic of ballet" [8, p. 62]. Moreover, as emphasized by N.V. Polyakova, "positive motivation and, first and foremost, the satisfaction of the cognitive need characteristic of children are necessary" $[28$, p. 410]. Thus, the stimulation of the student's natural abilities and inner creative resources occurs, which actively influences the educational process.

\section{Conclusions}

Musical and acting training in the earliest stages of development allows determining prospects for the further professional development of a dancer. Without learning to work on the role, a dancer will hardly be successful but will master methods useful in the pedagogical activity. The knowledge of music history and theory not only serves as the foundation of children's general culture, but also motivates them for further education, broadens their interests, and prepares the basis for the future development of professional skill in the field of art and culture. Only comprehensive pre-professional preparation of students of general education institutions allows bringing out all facets of a child's individuality and determining the direction of their further professional life.

\section{REFERENCES}

[1] M. K. Bulankina. Pedagogicheskie problem razvitiya muzykalnosti uchacschikhsya professionalnykh khoreograficheskikh uchebnykh zavedeniy [Pedagogical problems of the development of musicality in students of vocational choreographic education institutions], Vestnik KGPU im. V.P. Astafyeva, Vol. 4, No. 34, 23-26, 2015.

[2] D. I. Dmitrieva. Pedagogicheskie podkhody v obuchenii klassicheskome tantsu [Pedagogical approaches to teaching classical dance], Vestnik ChGPU, Vol. 7, 59-65, 2017.

[3] M. V. Pereverzeva, S. S. Umerkaeva, N. I. Anufrieva, M. L. Kats, I. S. Kazakova. Interdisciplinary Approach to the Mastering of the Music of the 20th Century, Journal of Advanced Research in Dynamical and Control Systems, Vol. 12, No. 3, 772-778, 2020.

[4] R. R. Avetisyan, S. K. Karyayeva, I. R. Datieva, I. S. Tuaeva, O. N. Totoeva. Comparative analysis of the psychological and pedagogical aspect of the formation of health culture and the dynamics of the incidence in schoolchildren, La Prensa Médica Argentina, Vol. 105, No. 9, 495-500, 2019.

[5] E. M. Logunova. Muzykalnoe vospitanie v structure khoreograficheskogo obrazovaniya [Music education in the structure of choreographic education]. Vestnik MGUKI, Vol. 4, No. 48, 170-173, 2012.

[6] L. G. Timoshenko. Usloviya osvoeniya predprofessionalnykh program $\mathrm{v}$ oblasti khoreograficheskogo iskusstva $\mathrm{v}$ uchrezhdeniyakh dopolnitelnogo obrazovaniya detey [The conditions of mastering pre-professional programs in choreography in additional education institutions for children], Vestnik TGPU, Vol. 8, No. 185, 114-117, 2017.

[7] N. S. Poselskaya. Znachenie russkoy shkoly klassicheskogo tantsa v sisteme khoreograficheskogo obrazovaniya [The role of the Russian school of classical dance in the system of choreographic education], Vestnik YaGU, Vol. 7, No. 1, 100-104, 2010.

[8] T. V. Bulgakova. Pedagogicheskie zadachi prepodavaniya akterskogo masterstva $\mathrm{v}$ sisteme srednego professionalnogo khoreograficheskogo obrazovaniya [Pedagogical tasks of teaching acting skill in the system of vocational choreographic education], Kazanskiy pedagogicheskiy zhurnal, Vol. 2, 61-63, 2018.

[9] P. Cylulko. The use of simple percussion instruments for 
stimulating the development of a child with disability and for support of their nearest family, Psychiatria i Psychologia Kliniczna, Vol. 19, No. 2, 226-231, 2019.

[10] D. Rose, A. Jones Bartoli, P. Heaton. Measuring the impact of musical learning on cognitive, behavioural and socio-emotional wellbeing development in children, Psychology of Music, Vol. 47, No. 2, 284-303, 2019.

[11] H. N. Shouldice. "Everybody has something": One teacher's beliefs about musical ability and their connection to teaching practice and classroom culture, Research Studies in Music Education, Vol. 41, No. 2, 189-205, 2019.

[12] Ye. N. Yakovleva. Vvedeniye v muzykalnoye prosvetitelstvo: uchebnoye posobiye [Introduction to music enlightenment: A study guide], Regional budgetary institution of culture "Operational printing sector", Kursk, 2016.

[13] S. L. Glebova. Muzykalnoye prosveshcheniye podrostkov v usloviyakh deyatelnosti muzykalnogo obshchestva: dis. ... kand. ped. nauk: 13.00.01 [Musical education of adolescents in the conditions of activity of musical society: dis. ... cand. ped. sciences: 13.00.01], Tambov, 2002.

[14] O. P. Melnik. Osobennosti muzykalno-prosvetitelskoy raboty uchitelya muzyki. Pedagogika iskusstva: voprosy istorii, teorii i metodiki: mezhvuzovskiy sbornik nauchnikh trudov [Features of the music and educational work of a music teacher. Pedagogy of art: questions of history, theory and methodology: interuniversity collection of scientific papers], Publishing Center "Science", Saratov, Vol. 5, 207-212, 2010.

[15] O. V. Sitnikova. Pedagogika i metodika razvitiya khudozhestvennoy deyatelnosti detey: uchebno-metodicheskoye posobiye [Pedagogy and methodology for the development of children's artistic activity: teaching aid], Direct Media, Moscow, 2016.

[16] Z. A. Gavrilova. Muzykalno-teatralnaya deyatelnost kak sredstvo formirovaniya umeniy tvorcheskogo vzaimodeystviya u uchashchikhsya detskoy shkoly iskusstv: dis. ... kand. ped. nauk: 13.00.02 [Musical and theatrical activity as a means of forming the skills of creative interaction among students of the children's art school: dis. .. cand. ped sciences: 13.00.02], Yekaterinburg, 2012.

[17] A. N. Kuznetsov. Muzykalno-teatralnaya deyatelnost kak faktor razvitiya navykov sotsialnoy adaptatsii u mladshikh shkolnikov: avtoref. dis. ... kand. ped. nauk: 13.00 .02 [Musical and theatrical activity as a factor in the development of social adaptation skills in elementary school students: author. dis. ... cand. ped. sciences: 13.00.02], Moscow, 2014.

[18] A. B. Nikitina. Rebenok na stsene: nauchno-metodicheskoye posobiye [A child on stage: a scientific and methodological manual], VTSKHT, Moscow, 2003.
[19] E. K. Andreykina. Probuxhdenie interesa k iskusstcu baleta cherez izobrazitelnoe tvorchestvo [Developing interest in ballet using visual arts], Vestnik TGU, Vol. 9, No. 53, 127-131, 2007.

[20] C. Cohrdes, L. Grolig, S. Schroeder. The development of music competencies in preschool children: Effects of a training program and the role of environmental factors, Psychology of Music, Vol. 47, No. 3, 358-375, 2019.

[21] E. V. Ovchinnikova. Sovremennaya programma i metodologiya klassicheskogo tantsa na nachalnom urovne khoreograficheskogo obrazovaniya [The modern program and methodology for teaching classical dance at the beginner level of choreographic education], Izvestiya TGU. Gumanitarnye nauki, Vol. 4, 529-534, 2013.

[22] A. V. Lobuteva, L. A. Lobuteva, O. V. Zakharova, S. A. Krivosheev, A. D. Yermolaeva. Specifics of problem-based learning in the pharmaceutical education process, Journal of Advanced Pharmacy Education \& Research, Vol. 9, No. 2, 131-136, 2019.

[23] S. Pivneva, D. Denisova, N. Vitkovskaya, R. Zakieva, E. Muraya, G. Ushakova. Advanced Information Technology: Automated and Individual Learning Systems, International Journal of Advanced Trends in Computer Science and Engineering, Vol. 8, No. 6, 3481-3487, 2019.

[24] M. Akhmetova, S. S. Kunanbayeva, M. Kassymbekova. Development of Metalanguage Competence through Content and Branch Training, Rupkatha Journal on Interdisciplinary Studies in Humanities, Vol. 11, No. 2, 2019.

[25] M. V. Pereverzeva. Khoreograficheskaya aleatorika M. Kanningema $\mathrm{v}$ kontekste mobilnykh proizvedeniy iskusstva [M. Cunningham's choreographic aleatory in the context of mobile works of art], Vestnik Akademii russkogo baleta im. A. Y. Vaganovoy, Vol. 4, No. 57, 71-90, 2018.

[26] V. Y. Nikitin. Innovatsionnye formy obucheniya $v$ khoreograficheskom iskusstve [Innovative forms of training in choreography], Vestnik MGUKI, Vol. 1, No. 69, 233-238, 2016.

[27] T. A. Yastrebova, M. N. Yuryeva. Sushchnost i struktura ispolnitelskikh navykov shkolnikov $\mathrm{v}$ khoreografii [The essence and structure of performance skills in choorepgraphy in schoolchildren], Gaudeamus, Vol. 15, No. $3,97-102,2015$.

[28] N. V. Polyakova. Motivatsiya poznavatelnoy deyatelnosti v oblasti estestvennonauchnykh znaniy obuchaushchikhsya v Akademii russkogo baleta im. A.Y. Vaganovoy [Motivation for cognitive activity in the field of natural sciences in students of A.Y. Vaganova Academy of Russian Ballet], Izvestiya Rossiyskogo gosudarstvennogo pedagogicheskogo universiteta im. A.I. Gertsena, Vol. 34, No. 74, 406-410, 2008. 